\title{
An 'apostle of futurity': William Blake as herald of a universal religious worldview
}

DOI:

10.1080/14714787.2018.1523685

\section{Document Version}

Accepted author manuscript

Link to publication record in Manchester Research Explorer

\section{Citation for published version (APA):}

Billingsley, N. (2018). An 'apostle of futurity': William Blake as herald of a universal religious worldview. Visual Culture in Britain, 19(3). https://doi.org/10.1080/14714787.2018.1523685

\section{Published in:}

Visual Culture in Britain

\section{Citing this paper}

Please note that where the full-text provided on Manchester Research Explorer is the Author Accepted Manuscript or Proof version this may differ from the final Published version. If citing, it is advised that you check and use the publisher's definitive version.

\section{General rights}

Copyright and moral rights for the publications made accessible in the Research Explorer are retained by the authors and/or other copyright owners and it is a condition of accessing publications that users recognise and abide by the legal requirements associated with these rights.

\section{Takedown policy}

If you believe that this document breaches copyright please refer to the University of Manchester's Takedown Procedures [http://man.ac.uk/04Y6Bo] or contact uml.scholarlycommunications@manchester.ac.uk providing relevant details, so we can investigate your claim.

\section{OPEN ACCESS}


This is an Accepted Manuscript of an article published by Taylor \& Francis in Visual Culture in Britain 19.3 (November 2018) available online:

http://www.tandfonline.com/10.1080/14714787.2018.1523685.

\title{
An 'apostle of futurity': William Blake as herald of a universal religious worldview
}

\begin{abstract}
This article examines a strand of William Blake criticism from the second quarter of the twentieth century that styled his work as an embodiment of a universal religious worldview. In particular, it focuses on the writings of Max Plowman and John Middleton Murry from the mid 1920 s to the early 1940s, for whom Blake's works were portals into eternity and the future, and who celebrated Blake as prophet of a spiritual Weltanschauung for the modern age. The article examines similar principles in the work of British artists in this period, and is framed by exploring a parallel between the Blake of Plowman and Murry, and the use of painter-poet's name for the Australian Blake Prize for religious art, inaugurated in 1950-51.
\end{abstract}

Keywords: William Blake, John Middleton Murry, Max Plowman, pacifism, religion, vision

In 1950, in Sydney, a Catholic priest, Michael Scott, and a Jewish art dealer, Richard Morely, determined to organize a prize for contemporary religious art. They wanted to bring religious art in Australia up to date, and to challenge the sentimental images that populated churches at the time. Established in 1951, it was named the Blake Prize. For the organizing committee, Blake embodied the qualities that they sought to promote:

they were keen to acknowledge the ecumenical dimension of the venture at a time of hard-line divisions between church denominations in Australia.

Besides, as they wrote in 1950: "Blake is timeless and, though not professing allegiance to any particular denomination, was perhaps the most Godpossessed painter of all time. Therefore it is the Blake prize."

Blake is figured as an archetype for religious art that transcends the strictures and divisions of organized religion. The Blake Book, published in 2011 to celebrate the prize's sixtieth

anniversary, takes as its frontispiece Blake's Creation of Eve (1822) (Figure 1); the implication is that Blake is the Christ-Creator figure, summoning the spiritual art of the Blake Prize - cast as Eve - into existence. Blake was made the namesake of this art prize because the committee saw in his work a spiritual imagination which reaches beyond his own context and into the future, embodying a universal, timeless religious imagination which was as relevant to that moment in the mid-twentieth century Australian art-world as to the work of one painter-poet in London at the turn of the nineteenth century.

This article is concerned with how a similar view of Blake emerged in a strand of Blake literature in Britain two decades earlier. Several key Blake publications in the 1920s and 1930s styled Blake as herald of a universal religion, a concern that mirrored the aims of certain British artists in this period, including Eric Gill and his circle, and neo-Romantics such as Cecil Collins. My focus here is particularly on the Blake writings of modernist critics Max Plowman (18831941) and John Middleton Murry (1889-1957). Their shared obsession with Blake ran deep through their friendship, as well as in their individual writings; for each, Blake's work was not merely a subject of study, but a creed which permeated his outlook on life. Murry called Blake an 'apostle of futurity', ${ }^{2}$ a title which reflects both critics' vision of Blake as heralding a modernist utopia, the pursuit of which they sought to promote in their own writings. Their chief works on Blake were Plowman's An Introduction to the Study of Blake (1927) ${ }^{3}$ and Murry's 
William Blake (1933); these publications are discussed here alongside their correspondence (with one another, and others) and other writings. I also explore how their visions of Blake resonate with the work of contemporaneous British artists.

Plowman, the elder of the two, had been bitten by Blake well before his forays into publishing on the painter-poet. By his own account, Plowman 'determined to set to work on ... a voyage of discovery' of Blake's symbolism after the 1913 Blake exhibition (discussed in this issue by Martin Myrone). ${ }^{4}$ A reluctant recruit in the First World War, he resigned as a conscientious objector after being sent home injured. His resignation letter stated: 'So wholly do I believe in the doctrine of the Incarnation (that God indeed lives in every human body) that I believe that killing man is always killing God. ${ }^{5}$ Plowman had been reading Blake in hospital, as evidenced in fleeting references in his letters. ${ }^{6}$ Fundamentally, Plowman found in Blake a vision of humanity as divine, and the same conviction ran throughout Plowman's own writing, and was the driving force behind his socialist and pacifist work.

Plowman's preoccupation with Blake begins to emerge with intensity in his correspondence in 1924-25. As this was the period immediately preceding the publication of his book, that is not surprising, but the sheer degree to which Blake dominates in this period is notable in Dorothy Plowman's edited collection of her husband's essays. Blake is the subject not only of letters to Blake scholars S. Foster Damon, Geoffrey Keynes, and Joseph Wicksteed, but also to friends without formal connections with literary or scholarly spheres. Blake ran so deeply in Plowman's consciousness that he later wrote to Murry: 'What am I to say about Blake ... When you've got a man in your bones only personal assault makes you vocal about him ... I haven't the brains to anatomize myself. ${ }^{, 7}$ And when Plowman's son, Tim, died aged eleven in 1928, he turned to Blake for consolation; as he wrote a decade later:

I've a cracked heart. But if you've read Blake you'll know that the Divine Vision appeared through the broken heart of Enitharmon; \& what little I know of the Divine Vision appeared to me when I found myself powerless before mortal fate ... It was the happiest moment of my life, for I looked through a gap in mortality \& saw the miracle of love. ${ }^{8}$

Plowman cites Blakean symbols and ideas in a manner similar to an evangelical Christian invoking biblical motifs in everyday discourse; his very worldview is filtered through Blake's universe of archetypes and mythological figures.

Plowman felt compelled to help the world to recognize the 'truth' of Blake:

Truth's like rain. It finds its own level in its own time \& its own time is the right time ... Blake will INEVITABLY come into his own, when the world is ready for him. And we, if we help the world to that, are only fulfilling, as it were, an inevitable law of Time.'

He belived that this was the time for Blake's truth to be heard. It was a message that belonged to a new era. Plowman was, as his friend Richard Ward described in introducing the second edition of Introduction, the same kind of writer as Blake: driven by imagination and creative energy, seeking to express eternal truths. ${ }^{10}$ Above all, it was the belief in the divinity of humanity, cited in his army resignation letter, that moved Plowman in writing about Blake; it was a conviction shared by subject and commentator, such that Introduction is as much Plowman's own manifesto as the reader's guide to the study of Blake that its title suggests.

Plowman makes clear that he is not approaching Blake as an intellectual problem; indeed, he believes that many struggle with Blake's work because they seek to codify his symbolism. To understand Blake, one must engage directly and imaginatively with his work; Introduction is Plowman's account of his own such quest with Blake. ${ }^{11}$ Blake is inspirational for 
Plowman as 'the prototype of the individual artist,' because in spite of the lack of understanding that Blake faced in his lifetime, he 'never trimmed, never potboiled, never dallied; above all, he never doubted his own inspiration. ${ }^{, 2}$ Foregrounding this idea in his opening pages, Plowman's Introduction invites more than its titular Study of Blake; Blake is presented as an archetype for a way of life. Blake's individualism becomes a spiritual vision of avant-garde culture, in which the artist's duty is to protect divine humanity from the banalities of mass culture and academicism. $^{13}$

Plowman had strong feelings about which writers on Blake were of value. For example, he admired Damon's William Blake: his Philosophy and his Symbols (1924), and lamented its lukewarm reception. His disgust prompted him to write to Damon to express his own enthusiasm, initiating a correspondence that extended over the following years. It seems to have been Damon who put Plowman on to reading Joseph Wicksteed, author of Blake's Vision of the Book of Job (1910); ${ }^{14}$ Wicksteed too became a regular correspondent. Conversely, Plowman thought that Charles Gardner's book (it is not clear whether he means Vision and Vesture or William Blake: The Man) looked 'worthless,' adding: 'Blake has been simply cursed by stupid selfopinionated people ...' ${ }^{15}$ Although Gardner, like Plowman, seeks to champion Blake as offering a religious vision relevant to the modern world, Plowman may have objected to the way in which, as Paul Barlow put it, Gardner:

continues aspects of the $19^{\text {th }}$ century tradition of progressive Christian appropriation of Blake. Essentially it [Vision and Vesture] is an attempt to argue that Blake represents a renewal and purification of Christian thought, one which both anticipates and trumps the insights of modern secular thinkers ... for Gardner, the discovery of the true value of Blake's work is a way to re-Christianise culture, while accepting the Blakean truth that the churches are the agents of the corruption of the Christian vision. ${ }^{16}$

Plowman resisted tying his Blakean religious vision too closely to any tradition - a hangover from his rejection of his own strict Brethren upbringing. He believed that to be truly religious is to do away with any attachment to dogma and instead to encounter truth through imagination, as Blake proclaimed. ${ }^{17}$

Curiously, Plowman wrote little directly about Blake's designs, in spite of having a strong conviction that Blake's images were essential to understanding his mythos. Plowman insisted repeatedly that Blake's writings should not be divorced from his visual works and mentions several times in letters that he would like to see a complete facsimile of Blake's illuminated books - a venture which was apparently not commercially viable. He wrote to Keynes: 'My feeling is that Blake the poet is hard to divorce from Blake the illuminator. The Songs of Innocence are, as Blake might say, "divided from their emanations," when they appear in cold type lifted from their beautiful decorations. ${ }^{18}$ And to Damon, of Keynes' The Writings of William Blake (1925): 'Keynes' Book only goes to rub in the importance of Blake's illustrations \& now to be kept without any access to the decorations - "decorations" is really the wrong word - of the Songs of I. \& E. irks. ${ }^{19}$ Curiously, however, when he wrote a note for Dent's 1927 facsimile of The Marriage of Heaven and Hell, Plowman only commented on the technical qualities of the designs, confining his comments on the meaning of the work to the text.

In Introduction, although there is little explicit comment on Blake's designs, Blake is unambiguously presented as an image-maker. For Plowman, Blake's works, visual and verbal, are portals into a 'universe of images. ${ }^{20}$ He identifies as Blake as producer of the 'Imaginative Image $^{21}$ - that is, Blake presents in his work the vision of his imaginative eye, the world as he saw it, rather than an objective lens onto the world. Plowman gives an example of this phenomenon in a rare explicit comment about one of Blake's images: The Reunion of the Soul and the Body from the designs to Robert Blair's The Grave (published, engraved by Schiavonetti, in 
1805) (Figure 2). Plowman views the image in the same spirit as he outlines for reading Blake, as described above:

When the most magnificent of Blake's designs to Blair's Grave was first published, the art critic ... of The Examiner, could only see in the rapturous meeting of the Body and Soul a female figure apparently diving into the mouth of a male one; and though no doubt his corporeal sight was good, such a critic would need to have scales removed from his eyes before he was really capable of seeing what Blake drew. ${ }^{22}$

For Plowman then, Blake's images present the viewer with a space that cannot be viewed literally. The female figure in The Reunion of the Soul and the Body criticized (by Robert Hunt) in The Examiner defies gravity not because Blake was an incompetent or clumsy designer, but because she is not intended to be read as a physical human body; rather, it is a representation of the soul: an imagined depiction of a non-physical entity. ${ }^{23}$ Indeed, for Plowman, Blake's pictorial method has 'lifted the art of painting for ever out of the ruck of mere representation. ${ }^{24}$ Hence, Blake is presented as a forerunner to avant-garde painting: 'What ... he ultimately tries to portray is the truth he has perceived, and this, as modern art powerfully instructs us, may be far removed from the impression commonly derived from an object.' 25 Elsewhere, Plowman compares viewing Blake's work to seeing a Cézanne: 'Blake's poems and pictures are not flat surfaces. Like the landscapes of Cézanne, it is their depth that interests us, and the deeper we look the more the image comes forth. ${ }^{, 26}$

What Plowman is describing in these passages about Blake's pictorial method is a Blake that mirrors aspects of British art in this period. Eric Gill, for example, like Blake, integrated his religious, social and artistic vision in his work; and analogous to Plowman's Blake as revealing rather than inventing truth in his work, Gill held that the artist is not a creator of Beauty but a servant to it. For Gill, true art does not strive for superficial 'loveliness' but to conform to the Absolute reality of Beauty. ${ }^{27}$ Elsewhere, the kinds of 'living images' that Plowman finds in Blake's work were being made by artists such as Gill's friend David Jones in works like Sanctus Christus de Capel-y-ffin (1925, Tate), where the crucified Christ is depicted in the Black Mountains, where Jones lived at the time. Here, spiritual truth is incarnated in the landscape of Jones' life. Jones himself admired Blake as one of the English school's 'masters of energy' - that same quality of vitality that Plowman celebrates. ${ }^{28}$

Returning to Plowman's Blake: his statement that critics such as Hunt, confused by Blake's work, need to have scales removed from their eyes is a reference to St. Paul's conversion on the Damascus road; the implication is that one needs to adopt a Blakean worldview in order to understand his work. Thus, whether reading or viewing Blake, one must, for Plowman, approach his work on its own terms, as imaginative images which act (though Plowman does not use the analogy) in a manner similar to icons: as windows onto another, truer, sphere of reality. It was the state of spiritual beauty that Plowman saw in this Blakean Weltanschauung that he sought to promote in his writings on Blake and other subjects, and in his pacifist campaigning. In John Middleton Murry, Plowman found a friend who shared similar ideals.

The pair met in 1929, two years after the publication of Plowman's Introduction; they were introduced by fellow socialist and pacifist Richard Rees, latterly editor of The Adelphi magazine (1930-38), which Murry founded in 1923. This was one of several literary-cultural periodicals edited by Murry in which he promoted a modernist vision of the arts. As a student he edited his own magazine, Rhythm, which ran from 1911-13 (called The Blue Review for its last two issues in 1913). There followed his editorship of the Athenaeum (1919-21), then The Adelphi (1923-27) and The New Adelphi (1927-30) until that editorship was handed over to Rees and 
later to Plowman (1938-41). Under Murry's editorship, these publications reflected the mystical humanism that pervaded his writings.

Plowman encouraged Murry to read Blake, and in 1931 wrote joyfully to a friend: 'A great event. Murry has been seduced into reading Blake. The old beggar has got him ... The result will be beyond expectation. ${ }^{29}$ Blake's influence emerges in Murry's writings for The Adelphi from this time, notably for our concerns in his series, 'Essays on Modern Religion,' which reflect Murry's broader endeavour to articulate and promote what he described elsewhere as 'a renewal of the religious consciousness. ${ }^{30}$ For example, in 'The Veil of Good and Evil,' Murry cites Blake in summing up his aims in the series:

To be religious, in the sense which I have tried to outline in these essays, is simply to be sane; ... to have become flexible to experience and perfectly obedient to that God, who as Blake said, "only acts and is in existing beings or men." 31

Thus, Murry found in Blake a prophet for his own theosophical principles ${ }^{32}$ - hence his styling Blake an 'apostle of futurity.' Murry's William Blake (1933) must be seen in the light of this endeavour to demonstrate Blake's relevance beyond his own time, to promote a universal religion, free from religious dogmatism, for the twentieth-century world.

Murry describes his aim in the book as 'an attempt to elucidate the doctrine of William Blake. ${ }^{33}$ Indeed, he had suggested calling it " "The Divine Humanity": The Doctrine of William Blake, ${ }^{34}$ but the publisher, Jonathan Cape advised the simpler formula. Murry agreed, replying: 'in reality, it would not be misleading, since I am pretty certain that my book ... exhibits the personality and nature of Blake more completely than any other. ${ }^{35}$ Blake the man and Blake's work are of the same essence for Murry; in Murry's reading, Blake's: 'one purpose was to teach men what he believed to be the truth. What he tried to teach, I have tried to expound: nothing more and nothing less. ${ }^{36}$

Murry explains his decision to confine himself to addressing Blake's writings in his preface. Focusing on this aspect of Blake's work has allowed him to set his evidence before the reader together with his argument. By contrast, he states: 'An attempt of the same kind made on the evidence of Blake's designs would be involved in innumerable technical difficulties; and, even if these were overcome (and I, personally, would be quite incapable of overcoming them) the ensuing book would be prohibitively expensive. ${ }^{37}$ As seen above, costs associated with the production of images was apparently also a barrier to Plowman's ambitions for facsimiles of Blake's illuminated books, and has been an enduring factor in the relative weight of critical attention given to Blake's designs versus his writings (although today an ever-growing number of Blake's designs are readily accessible online via the Blake Archive and elsewhere). However, selected Blake books were printed in facsimile, including those by Dent with notes by Plowman (Marriage of Heaven and Hell, 1927) and Murry (Visions of the Daughters of Albion, 1933), though neither discusses the content of the designs (Plowman makes a handful of general comments about the visual aspects of Blake's work, such as 'Blake was an imaginative poet: he thought in images,' and Murry only comments that Visions of the Daughters of Albion is one of Blake's 'most beautiful' prophetic books). ${ }^{38}$

There was an exchange between Murry and Cape about illustrations for William Blake. A few months before publication, Murry asked Cape's opinion on this matter; Murry's only request was for an unspecified reproduction of a page from The Four Zoas, though he added that he could easily suggest more. ${ }^{39}$ The book was published without illustrations, and I have been unable to deduce which leaf from The Four Zoas Murry is likely to have had in mind. Murry makes only general observations about the drawings in the manuscript, at the beginning of his section on The Four Zoas: he notes that they are 'beautiful,' and mentions the controversial 
nature of their sexually explicit content. ${ }^{40}$ Whether the final decision not to include any illustrations in Murry's book can be attributed to production costs, the relative indifference of the author, or another factor - or combination of reasons - I have been unable to ascertain. But any such material would have been more augmentation or illumination of Murry's text than illustration, since apart from the sort of general comments cited above, his focus is squarely on Blake's writings.

Murry's account of Blake's doctrine is a narrative of evolution, which culminates in Milton (1804-c.1811) and is articulated anew in Blake's late works such as Jerusalem (1804c.1820) and The Everlasting Gospel (c.1818). For Murry, the essence of Blake's doctrine consists of three concepts: forgiveness as the central principle, self-annihilation as the means through which this is achieved, and Eternity as the reality in which this takes place. Blake's notion of self-annihilation, which appears in Milton, is that the individual must surrender his or her selfhood (what we might now call the ego) in order to embody his or her true and eternal self. Eternity is the reality from which Blake writes and into which his doctrine seeks to move his reader. ${ }^{41}$ It is Blake's 'forward leap into Eternity' ${ }^{42}$ - his own self-annihilation - which is at once Blake's greatest achievement, for Murry, and which presents an especial problem in interpreting him. In an echo of Plowman's opinion that Blake must be read and viewed in his own terms, in the realm of Imagination, Murry states that the difficulty with Blake is that he 'had to speak the meaning of Eternity in the language of Time' and this inevitably led to incomprehension of his message (again, we are seeing Murry's idea of Blake as an 'apostle of futurity'). ${ }^{43}$

Murry's William Blake was, by his own account, begotten by Plowman, who suggested that his friend write on the subject, provided access to his collection of books on Blake, and read the manuscript twice. ${ }^{44}$ Plowman's impressions of Murry's book are recorded in their correspondence. Plowman's general tenor is enthusiasm, and he told Murry several times that he believed that the work captured the essence of Blake as no commentator had before: 'I have the delicious sense of a man moving somewhere near Blake's depths of consciousness \& think this is such a delight after what one has suffered in the way of Blake exposition. ${ }^{45}$ Again, the language is of entering into another domain in reading Blake. Plowman also enthused about Murry's manuscript to other correspondents; writing to Mary Marr, Plowman asked:

Did I tell you John sent me $3 / 4$ of his Blake book to annotate? ... John has the greatest insight of anybody living ... although his enemies will say (with some truth) that he has now made Blake in his own image ... the book is a completely sane and reasoned vindication of Blake. And that has never been produced before. ${ }^{46}$

Nevertheless, Plowman criticized Murry for a tendency to prioritize intellect over faith; to the same correspondent, Plowman wrote:

John mistrusts what he knows but can't verify with his intellect ... And that is what faith is. To the intellect it seems stupid ... But it is the creative sign of self-annihilation the committal of the whole being to life in spontaneous trust ... It is the way of joy ... John stops short of all this. ${ }^{47}$

It is, however, the shared concerns of these critics, rather than the differences in their emphases, that are relevant to their championing of Blake as herald of universal religion, whom they believed heralded truths for the modern world.

Plowman's letters to Murry reveal the depth of their shared obsession with Blake as a luminary figure: they are littered with Blakean aphorisms which flow naturally in Plowman's prose, as if quoting a shared creed. Blake references appear in a similar manner in many of Murry's essays in The Adelphi on a variety of topics. For both, their Blakean philosophy was 
closely linked to their pacifism. Though they disagreed about the cart and the horse (Plowman believed that a Blakean worldview engendered socialism and pacifism, and criticized Murry for seeing the link the other way round, risking preaching socialism as a religion), ${ }^{48}$ they shared a concern to strive for a Blakean future - a new Jerusalem in which pacifism and socialism prevailed. To this end, in 1934 the pair set up the Adelphi Centre on a farm in Essex, purchased by Murry. Taking the name of Murry's magazine, the centre was a pacifist and socialist commune, where these principles were to be studied and practiced. In the event, the original Centre was short-lived, but the site continued to be used for projects in keeping with the pair's ideals, including in partnership with the Peace Pledge Union, of which Plowman was the General Secretary in 1937-38. ${ }^{49}$

In terms of Blakean motives, the most important incarnation of the Centre was that on which Plowman was working when he died in 1941. It was to be, as Dorothy Plowman described, a community founded on 'the simple and eternal aspiration of the common man and woman: to live in true creative peace as members of the human-divine family,' over which 'no creed, religious or political, would be allowed to take precedence. ${ }^{50}$ The mission statement for the new Adelphi Centre, penned by Plowman in 1941, is strikingly Blakean. Plowman sets out its purposes as threefold: the house and grounds were to be a meeting place for pacifists; the Centre would support the subsistence farmers on the adjacent land; the Community Land Training Association was to employ experienced farmers to train young people to take up farming. Plowman invokes Blake to validate the numerical division of the Centre's purposes: 'Blake said "The sexual is the threefold: the human is the fourfold." God grant that in pursuit of the threefold we may realise the fourfold - that the Adelphi Centre may have the Divine-

Humanity as its centre \& pole-star. ${ }^{51}$ The manifesto concludes with a clarion call taken directly from Blake:

To each upon his own level -- \& to none more deeply or more powerfully than to the pacifists of whom he was the most truly English forbear - William Blake now sounds his trumpet call:

England! awake! awake! awake!

Jerusalem thy sister calls!

Why wilt though sleep the sleep of death?

And close her from thy ancient walls.

Our immediate task - to-day - is the joyful labour of working towards the practical realisation of his vision. ${ }^{52}$

Here, in the Second World War, Blake is invoked as a prophet for a pacifist utopia, a community or brotherhood of shared labour, with divine humanity at its heart. ${ }^{53}$ Since Plowman died in 1941, and the site was taken over for the war effort the following year, this idyll was not to last, and the Adelphi Centre closed in 1942.

The Plowman-Murry model of Blake as herald of a non-dogmatic, universal religious worldview emerges from a broader modernist concern in the interwar years to shape a new worldview, and with it new languages in art, literature, and religion. These concerns abound in The Adelphi ${ }^{54}$ and numerous other publications in the period. And, as Bankes and Hills note in their study of Jones, with 'storm clouds gathering over Europe ... [a]rtists were looking inwards ... sensing the need to reconnect with the Romantic tradition. ${ }^{55}$ Plowman and Murry found in Blake a Weltanschauung which they adopted as a creed, and sought to champion in their writings. Their take on Blake is akin to the spirit of Ananda Coomaraswamy's philosophical writings, which sought to bridge Eastern and Western philosophies and to open up social implications for the modern age (Coomaraswamy himself had an interest in Blake, as noted in 
Colin Trodd's article in this issue). Elsewhere, Cecil Collins' essay Vision of the Fool (1944), written to accompany an exhibition of his work, celebrated 'purity of consciousness' that participated in "sur-reality", by which he means, reality which is 'universal and eternal, above and beyond the world of the intellect and the senses; but not beyond the reach of the humility and hunger of the human heart. ${ }^{56}$

It is really a single, central doctrine in Blake's work that appeals to critics like Plowman and Murry: namely, his vision of the divinity of humanity. ${ }^{57}$ From this idea the notion of universal religion emerges, for if every individual is regarded as divine, then every human act and interaction is religious. In other words, the notion of the divinity of humanity engenders a worldview which transcends all religious and political divisions, and which simply values everyone and everything. Blake presents this proto-modernist Weltanschauung in his poetry and designs; the apparent strangeness of these works is, for Plowman and Murry, indicative of the authenticity of the creator's vision. For them, Blake's work emerges from, and leads its reader or viewer to, a truer state of reality than the mire and dross of everyday life. Blake's world is at once a world of eternity, and of an imagined, ideal future. Hence, he is a pole-star for modernist culture - an 'apostle of futurity.'

I noted in my opening comments a parallel between the Blake of Plowman and Murry, and the Blake of the Blake Prize for religious art, born in 1950. Like these critics, the prize invokes Blake as a luminary for a non-dogmatic, timeless religious vision. And in The Blake Book, Blake's Creation of Eve appears as an emblem of his enduring capacity to generate pure creativity, as embodied in the figure of the universal woman, Eve. This image could also stand as an emblem for the Blakean vision of Plowman and Murry in which the Creator-Christ can be read as Blake summoning a vision of unfettered, divine humanity into existence, or as PlowmanMurry summoning that vision from Blake's works (figured as Adam). Like the figure in The Reunion of the Soul and the Body, Blake's Eve defies gravity and so too epitomizes the mode of reading and viewing Blake proposed by these critics; namely, that Blake's works are portals to a vision of reality that offered a universal religious worldview for the modern - and the future age.

\section{Acknowledgements}

I am grateful to Colin Trodd for his valuable comments on earlier drafts of this article; to the Bishop Otter Trust for funding the archival research; and to the individuals and institutions that have granted permission to include their material here.

Naomi Billingsley is a Leverhulme Early Career Fellow at the University of Manchester.

\section{Notes}

${ }^{1}$ Crumlin, The Blake Book, 14, citing 'Blake Minutes' dated October 18, 1950. Such figurings of Blake were articulated in this period by writers such as Frye (Fearful Symmetry, 1947), Raine (William Blake, 1951), and the contributors to Pinto (The Divine Vision, 1957).

${ }^{2}$ Murry, 'Note' in Blake, Visions of the Daughters of Albion, 20.

${ }^{3}$ Plowman also edited The Poems \& Prophecies of William Blake (1926).

${ }^{4}$ Plowman to S. Foster Damon, October 13, 1924, A Bridge into the Future, 180. 
${ }^{5}$ Plowman to the Adjutant, $52^{\text {nd }}$ (Grad.) Bn. Durham Light Infantry, January 14, 1918, A Bridge into the Future, 92.

${ }^{6}$ To Janet Upcott, April 29, 1917 \& February 26, 1918; to Hugh de Selincourt, May 5, 1917, August 8, 1917 \& Aug. 25 ${ }^{\text {th }}$ 1917: Plowman, Bridge into the Future, 65, 100, 66, 75-76, 79.

${ }^{7}$ Plowman to J. Middleton Murry, October 25 1929, A Bridge into the Future, 322. Cf.

Plowman, Max, Letter to John Middleton Murry, October 25, 1929, UCL GB0103. Material from the Plowman papers at UCL is quoted by kind permission of Greta Plowman.

${ }^{8}$ Plowman to Richard H. Ward, March 27. 1938, A Bridge into the Future, 622.

${ }^{9}$ Plowman to Dorothy Plowman, c.1924-25?, A Bridge into the Future, 178.

${ }^{10}$ Ward, 'Max Plowman and Blake', vii-viii.

${ }^{11}$ Plowman, An Introduction to the Study of Blake, xix-xxii.

${ }^{12}$ Ibid., 16.

${ }^{13}$ These matters are explored in Bertholf and Levitt, eds., William Blake.

${ }^{14}$ Plowman to S. Foster Damon, November 11 1924, A Bridge into the Future, 186.

${ }^{15}$ Ibid.

${ }^{16}$ Barlow, 'John Rylands Library - Blake Project', §2a.

${ }^{17}$ These ideas are explored in Plowman's essay 'William Blake and the Imagination of Truth.'

${ }^{18}$ Plowman to Geoffrey Keynes, October 8, 1924, A Bridge into the Future, 179.

${ }^{19}$ Plowman to S. Foster Damon, January 20, 1926, A Bridge into the Future, 211.

${ }^{20}$ Plowman, An Introduction to the Study of Blake, 19.

${ }^{21}$ Ibid., 24ff.

${ }^{22}$ Ibid., 24.

${ }^{23}$ Ibid., 25.

${ }^{24}$ Ibid., 27.

${ }^{25}$ Ibid., 100.

${ }^{26}$ Ibid., 32.

${ }^{27}$ These ideas are articulated numerous times by Gill; an early example is his pseudonymous essay on his Westminster Cathedral Stations of the Cross (1914-18), in response to criticism about their stark, linear style. For Gill, because Beauty is an absolute, it is not in the eye of the beholder, but in the truth of the artist's convictions. Rowton, 'The Stations of the Cross in Westminster Cathedral', 51.

${ }^{28}$ Bankes and Hills, The Art of David Jones, 112.

${ }^{29}$ Plowman to Mrs. Orgill MacKenzie, March 5, 1931, 371.

${ }^{30}$ Murry, Letter to Jonathan Cape, July 14, 1924, Cape A29. Material from the Jonathan Cape Archive (now part of the Random House Group Archive) is quoted by kind permission of the Society of Authors as the Literary Representative of the Estate of John Middleton Murry and The Random House Group Ltd. This is from a paragraph written for the publisher by Murry to promote his book To the Unknown God.

${ }^{31}$ Murry, 'The Veil of Good and Evil', 96.

${ }^{32}$ As Paul Barlow has shown, a similar process occurred in relation to aligning Blake with Indian culture; writers such as John Gould Fletcher, writing in The Aryan Path in 1930, identified Blake's worldview as resonating with Hindu spirituality and culture. Barlow, 'The Aryan Blake.'

${ }^{33}$ Murry, William Blake, 7.

${ }^{34}$ Murry, Letter to Jonathan Cape, March 4, 1933, Cape A29.

${ }_{35}^{35}$ Murry, Letter to Jonathan Cape, May 5, 1933, Cape A29.

${ }^{36}$ Murry, William Blake, 8.

${ }^{37}$ Ibid., 7. 
${ }^{38}$ Plowman, 'Note' in Blake, The Marriage of Heaven and Hell, 8; Murry, 'Note', 11. The most ambitious illustrated Blake book in this period was Darrell Figgis' 1925 The Paintings of William Blake, which included one hundred plates. Figgis writes about Blake with enthusiasm that may be likened to religious zeal, but he is not promoting a Blakean worldview as Plowman and Murry do.

${ }^{39}$ Murry, Letter to Jonathan Cape, April 7, 1933, Cape A29.

${ }^{40}$ Murry, William Blake, 153.

${ }^{41}$ Ibid., 236-55.

${ }^{42}$ Ibid., 258.

${ }^{43}$ Ibid., 369-70.

${ }^{44}$ Ibid., 8.

${ }^{45}$ Plowman, Letter to John Middleton Murry, May 26, 1932. UCL GB0103.

${ }^{46}$ Plowman, Letter to Mrs. Mary Marr, 3 March 1933, A Bridge into the Future, 460.

${ }^{47}$ Plowman, Letter to Mrs. Mary Marr, 20 Oct. 1933, A Bridge into the Future, 476.

${ }^{48}$ Plowman, Letters to John Middleton Murry, May 30, 1930; November 14, 1932. UCL GB0103.

49 The PPU developed from Canon Dick Sheppard (of St. Paul's Cathedral)'s 'pacifist pledge,' which invited individuals to write to him, declaring never to support war. Notable 'sponsors' of the PPU included Aldous Huxley (who would in 1954 publish Doors of Perception, which takes its name from Blake's Marriage of Heaven and Hell), Bertrand Russell, Siegfried Sassoon and Vera Brittain. John Hargrave, the founder-leader of the Kibbo Kift, shared some of the values of the PPU, and, like Plowman and Murry, was a great Blake admirer.

${ }^{50}$ Dorothy Plowman, 'Preface', in Plowman Bridge into the Future, 11.

${ }^{51}$ Plowman, A Bridge into the Future, 775.

${ }^{52}$ Ibid.

${ }^{53}$ Paul Bloomfield similarly invoked Blake as a voice relevant against the 'great outrages of power' in Europe in 1940. Bloomfield, 'William Blake and his Albion', 845.

${ }^{54}$ Religion was a particular focus in The Adelphi in 1931 when Murry published his series of essays on modern religion, leading to a group of essays in No. 4 by the members of 'The Adelphi Forum' expressing various views on the subject. Murry, 'The Veil of Good and Evil'; Plowman, 'God, Faith and Mr. Murry'; Hyde, 'Religion and the Adelphi'; Murry, 'The Faith of Unfaith'; Jones, 'God, Faith and Mr. Murry'; Rees, 'Mr. Plowman's Dualism'; Plowman, 'Dualism and Spiritual Life'; Rees, 'Notes and Comments.'

${ }^{55}$ Bankes and Hills, The Art of David Jones, 127.

${ }^{56}$ Collins, 'The Vision of the Fool', 32.

${ }^{57}$ A similar idea appears on the other side of the Atlantic in William F. Clarke's 1929 article 'The Significance of William Blake in Modern Thought,' which argues for the value of Blake's doctrine of the divinity of humanity for modern philosophy.

\section{Bibliography}

Bankes, Ariane and Paul Hills, The Art of David Jones: Vision and Memory, Farnham: Lund Humphries, 2015.

Barlow, Paul, 'The Aryan Blake: Hinduism, Art and Revelation in William Blake's Pitt and Nelson Paintings', Visual Culture in Britain, 12.3 (2011): 277-92.

Barlow, Paul, 'John Rylands Library - Blake Project', unpublished report, Manchester: The John Rylands Library, 2014. 
Bertholf, Robert, J., and Annette S. Levitt, William Blake and the Moderns, Albany: State University of New York, 1988.

Blake, William, ed. David V. Erdman, The Complete Poetry and Prose of William Blake, New York: Doubleday, 1988.

Blake, William, ed. Geoffrey Keynes, The Writings of William Blake, London: The Nonesuch Press, 1925.

Blake, William, ed. Max Plowman, The Poems \& Prophecies of William Blake, London: J. M. Dent \& Sons, 1927.

Blake, William, and Max Plowman, The Marriage of Heaven and Hell, reproduced in Facsimile... with a Note by Max Plowman, London and Toronto: J. M. Dent \& Sons, 1927.

Blake, William, and John Middleton Murry, Visions of the Daughters of reproduced in Facsimile... with a Note by John Middleton Murray, London and Toronto, J. M. Dent and Sons Limited.

Bloomfield, Paul, 'William Blake and his Albion', Journal of the Royal Society of Arts 88.4569 (1940): 844-46.

Clarke, William F., 'The Significance of William Blake in Modern Thought', The International Journal of Ethics 39.2 (1929): 217-30.

Collins, Cecil, 'The Vision of the Fool' in The Vision of the Fool: Early Drawings by Cecil Collins (London: Anthony d'Offay Gallery, 1991).

Crumlin, Rosemary; ed. Margaret Woodward, The Blake Book: Art, Religion and Spirituality in Australia. Celebrating 60 Years of the Blake Prize, Melbourne: Macmillan, 2011.

Damon, S. Foster, William Blake: His philosophy and symbols, London: Constable, 1924.

Figgis, Darrell, The Paintings of William Blake, London: Ernest Benn, 1925.

Fletcher, John Gould, 'Blake's Affinities with Oriental Thought', The Aryan Path 1 (1930): 581 86.

Frye, Northrop, Fearful Symmetry: A study of William Blake, Princeton: Princeton University Press, 1947.

Gardner, Charles, William Blake, the Man, London: J. M. Dent \& Sons Ltd, 1919.

Gardner, Charles, Vision and Vesture: A study of in William Blake in modern thought, London: J. M. Dent, rev. edn. 1929.

Hyde, Lawrence, 'Religion and “The Adelphi”', The Adelphi 2.4 (1931): 275-82.

Jones, E. B. C, 'God, Faith and Mr. Murry', The Adelphi 2.4 (1931): 285-86. 
Murry, John Middleton, To the Unknown God: Essays towards a religion, London: Jonathan Cape, 1924.

Murry, John Middleton, 'Essays on Modern Religion: IV. The Imaginative Consciousness', The Adelphi 1.5 (1931): 362-70.

Murry, John Middleton, 'Essays on Modern Religion: VI. The Eternal Man', The Adelphi 2.1 (1931): 5-13.

Murry, John Middleton, 'Essays on Modern Religion: VII. The Veil of Good and Evil', The Adelphi 2.2. (1931): 93-100.

Murry, John Middleton, 'The Faith of Unfaith', The Adelphi 2.4 (1931): 283-85.

Murry, John Middleton, William Blake, London: Jonathan Cape, 1933.

Murry, John Middleton, Letters to Jonathan Cape, University of Reading Special Collections. Cape A29.

Pinto, Vivian De Sola, ed., The Divine Vision, London: Victor Gollancz Ltd., 1957.

Plowman, Max, 'William Blake and the Imagination of Truth', The New Adelphi 3.3 (1930):

$177-83$.

Plowman, Max, 'God, Faith and Mr. Murry', The Adelphi 2.3 (1931): 249-56.

Plowman, Max, 'Dualism and Spiritual Life', The Adelphi 2.4 (1931): 287-89.

Plowman, Max, ed. Dorothy L. Plowman, Bridge into the Future: Letters of Max Plowman, London: Andrew Dakers Limited, 1944.

Plowman, Max, An Introduction to the Study of William Blake, London: Frank Cass \& Co Ltd., 2nd edn. 1967.

Plowman, Max, Letters to John Middleton Murry. University College London Special Collections (UCL), GB0103.

Raine, Kathleen, William Blake, London: Longmans, Green and Co., 1951.

Rees, Richard, 'Mr. Plowman’s Dualism', The Adelphi 2.4 (1931): 286-87.

Rees, Richard, 'Notes and Comments', The Adelphi 2.5 (1931): 367-71.

Rowton, E., 'The Stations od the Cross in the Cathedral', Westminster Cathedral Chronicle 12 (1918): 50-53.

Ward, R. H., 'Max Plowman and Blake', in An Introduction to the Study of Blake, by Max Plowman, vii-xxii. London: Frank Cass \& Co Ltd., 2nd edn. 1967. 


\section{Captions:}

Figure 1: William Blake, The Creation of Eve 1822, illustration for Paradise Lost by John Milton (VIII, 452-77) pen and brown and black ink and watercolour over pencil and black chalk, with stippling and sponging, 50.4 x $40.7 \mathrm{~cm}$ (sheet), National Gallery of Victoria, Melbourne, Felton Bequest, 1920 (1024-3)

Figure 2: Luigi Schiavonetti, after William Blake, The Reunion of the Soul \& the Body / The Grave, A Poem, by Robert Blair, 1808, published 1813. Etching, Yale Center for British Art, Paul Mellon Collection 